\title{
$\begin{array}{lllllllllllllllllll} & \mathrm{O} & \mathrm{R} & \mathrm{Z} & \mathrm{E} & \mathrm{C} & \mathrm{Z} & \mathrm{N} & \mathrm{I} & \mathrm{C} & \mathrm{T} & \mathrm{W} & \mathrm{O} & \mathrm{S} & \text { A } & \mathrm{D} & \mathrm{O} & \mathrm{W} & \mathrm{E}\end{array}$
}

Ks. Wojciech Góralski

Ius Matrimoniale

$30(2019) \mathrm{nr} 2$

DOI:10.21697/im.2019.30.2.06

Wydział Prawa Kanonicznego UKSW

ORCID: 0000-0001-6548-4120

\section{Podstępne wprowadzenie w błąd (kan. 1098 KPK) w opublikowanych orzeczeniach Roty Rzymskiej z lat 2010-2012}

Treść: Wstęp. 1. Podstępne wprowadzenie w błąd jako czynnik chroniący zgodę małżeńską. 2. Działanie podstępne. 3. Błąd jako skutek działania podstępnego. 4. Przymiot osoby jako przedmiot działania podstępnego. 4.1. Przymiot osoby in genere. 4.2. Przymioty osoby w przebadanych orzeczeniach. 5. Dowodzenie deceptio dolosa. Uwagi końcowe.

\section{Wstęp}

Ukształtowanie przez nupturienta zgody małżeńskiej, a więc aktu osobistego wyboru małżeńskiego, stanowi pewien proces, który wymaga instytucjonalnej ochrony umożliwiającej osiągnięcie właściwego poznania nie tylko samego małżeństwa, lecz również przyszłego współmałżonka. W tym drugim przypadku wyrazem owej ochrony jest usankcjonowanie przez ustawodawcę nieważności małżeństwa w sytuacji braku wystarczająco prawdziwego poznania konkretnej osoby jako przyszłego małżonka. Chodzi więc o kan. 1097 \$ 1 KPK (błąd co do osoby), kan. $1097 \$ 2$ KPK (błąd co przymiotu osoby zamierzonego bezpośrednio i zasadniczo) i kan. 1098 KPK (podstępne wprowadzenie w błąd $)^{1}$. Ten ostatni brzmi następująco: „Kto zawiera

1 Zob. P.J. VILADRICH, Konsens małżeński. Sposoby prawnej oceny i interpretacji w kanonicznych procesach o stwierdzenie nieważności małżeństwa (kanony 1095-1107 
małżeństwo zwiedziony podstępem, dokonanym dla uzyskania zgody małżeńskiej, a dotyczącym jakiegoś przymiotu drugiej strony, który ze swej natury może poważnie zakłócić wspólnotę życia małżeńskiego, zawiera je nieważnie".

Tak określona figura prawna (deceptio dolosa), należąca do kategorii error facti, wprowadzona dopiero przez obowiązujący KPK, stanowiąca wyraz hołdowania przez ustawodawcę personalistycznej wizji małżeństwa, wypełnia dotkliwą lukę istniejącą przez stulecia w kościelnym ustawodawstwie małżeńskim.

Szybki rozwój doktryny i orzecznictwa rotalnego w przedmiocie podstępnego wprowadzenia w błąd (inaczej błędu spowodowanego podstępem) przyniósł znaczące rezultaty, gdy chodzi o kierunki interpretacyjne w odniesieniu do poszczególnych elementów normy prawnej; wypracowano ponadto określone zasady dotycząc dowodzenia deceptio dolosa.

Przedmiotem niniejszego studium jest orzecznictwo Trybunału Roty Rzymskiej w zakresie podstępnego wprowadzenia w błąd pochodzące z lat 2010-2012, zawarte w Decisione seu sententiae. W wymienionym okresie interesujący nas tytuł nieważności małżeństwa został rozpoznany w dwunastu sprawach (odrębnie lub łącznie $z$ innym tytułem lub tytułami); spośród wyroków, które w nich zapadły aż dziesięć zostało opublikowanych: w roku 2010 - 3, w 2011 - 2, w 2012 - 5 (dwa niepublikowane pochodzą z 2010 i 2011 roku).

W powszechnie przyjętej doktrynie kanonistycznej oraz w orzecznictwie rotalnym uznaje się, że istotnymi elementami deceptio dolosa są: działanie podstępne (intencja i cel), błąd powstający u współkontrahenta jako skutek działania podstępnego oraz przedmiot podstępu ${ }^{2}$. W wyroku c. Erlebach z 4 października 2012 roku wymienia się cztery elementy tej figury prawnej: a) działanie podstępne; b) błąd, w który popada ofiara działania podstępnego; c) określony

Kodeksu Prawa Kanonicznego), tłum. S. ŚwiAczny, Warszawa 2002, s. 161-164; W. Góralski, G. Dzierżon, Nieważność małżeństwa zawartego pod wpływem podstępu. Kan. 1098 Kodeksu Prawa Kanonicznego, Warszawa 2004, s. 12-13.

2 Dec. C. Arellano Cedillo z 01.06.2011, RRD 103 (2011), s. 269, n. 4. 
cel działania podstępnego; d) przymiot osoby jako przedmiot działania podstępnego i błędu ${ }^{3}$. Cel działania podstępnego można jednak „pomieścić” w obszarze działania podstępnego.

Prezentacja orzecznictwa Roty Rzymskiej, o którym mowa, zostanie ukazana w obrębie owych elementów składających się na deceptio dolosa oraz dowodzenia tego tytułu nieważności. Czymś jednak bardziej podstawowym jest ukazanie nowego tytułu nieważności w perspektywie zgody małżeńskiej, co wskazuje na ratio legis kan. 1098 KPK.

\section{Podstępne wprowadzenie w błąd jako czynnik chroniący zgodę małżeńską}

Mając na uwadze określenie małżeństwa przez Konstytucję duszpasterską Gaudium et spes Soboru Watykańskiego II jako „głęboką wspólnotę życia i miłości małżeńskiej ustanowioną przez Stwórcę i unormowaną Jego prawami, zawiązującą się przez przymierze małżeńskie, czyli przez nieodwołalną osobistą zgodę"4, należy przyjąć, że zgoda małżeńska będąca fundamentem małżeństwa, powinna odznaczać się dwiema cechami: prawdą i wolnością. Jak stwierdza się w wyroku c. Sciacca z 25 czerwca 2010 roku, cały rozdział kodeksowy De consensu matrimoniali usiłuje w swoich normach promować prawdę i wolność konsensu małżeńskiego. Gdy chodzi o prawdę, czyli szczerość, to należy przywołać przede wszystkim normy o błędzie, tak faktycznym (kan. 1097 KPK) jak i prawnym (kan. 1099 KPK), a także o dokonanym dobrowolnie oszustwie, czy to w stosunku do samej instytucji (kan. 1101 KPK) czy też współpartnera (kan. 1098 $\mathrm{KPK})^{5}$. Prawo przywiązuje wagę również do niektórych poważniejszych okoliczności, które mogą przeszkodzić wspólnocie całego życia,

\footnotetext{
3 Dec. c. Erlebach z 04.10.2013, RRD 104 (2012), s. 251, n. 4; Dec. C. Erlebach z 14.12.2012, RRD 104 (2012), s. 382, n. 3.

4 Konstytucja duszpasterska „Gaudium et spes” Soboru Watykańskiego II, n. 48, w: Sobór Watykański II. Konstytucje, Dekrety, Deklaracje, Pallotinum 1967.

5 Dec. C. Sciacca z 25.06.2010, RRD 102 (2010), s. 263, n. 3.
} 
jak właśnie podstęp co do przymiotu drugiej strony, który może poważnie zakłócić wspólnotę życia małżeńskiego (kan. 1098 KPK) ${ }^{6}$.

Słusznie więc, zauważa wymieniony ponens, nic bardziej nie stoi na przeszkodzie dwóch osób ujętych w ich godności duchowej, w akcie, który zobowiązuje je na całe życie, jak podstęp jednej wobec drugiej co do przymiotu, którego istnienie lub brak jest znaczące dla wspólnoty życia ${ }^{7}$. „Nigdzie wolność nie jest tak konieczna, jak w małżeństwie”, głosi wyrok c. Pinto z 25 listopada 2011 roku, przytaczając zdanie Kwintilianusa (z I wieku po Chr.) ${ }^{8}$.

Ochronę zgody małżeńskiej w kan. 1098 KPK można dostrzec również w tym, iż wymieniony kanon stanowi wyjątek od zasady generalnej wpisanej do kan. $125 \$ 2$ KPK, w myśl którego „akt dokonany [...] na skutek podstępu jest ważny, chyba że prawo zastrzega inaczej; może być jednak rozwiązany wyrokiem sędziego[...]”. Jak podkreśla się w orzeczeniu c. Huber z 28 kwietnia 2010 roku, z kan. $125 \$ 2$ wynika, że podstęp nie unieważnia aktu prawnego, nie znosi bowiem voluntarium; wola jest dotknięta wadą, lecz nie tak, by była nieważna9.

Zważywszy jednak na nierozerwalność małżeństwa oraz na konieczność właściwego ukształtowania zgody małżeńskiej nupturientów, należy przyjąć, iż ustawodawca pragnie ich chronić przed działaniem podstępnym, które sprawiałoby, że przyczyną sprawczą

\footnotetext{
6 Tamże.

7 Tamże, n. 4. Ponens powołał tutaj pracę: O. Fumagali Carulli, Il matrimonio Canónico opoi l Consilio. Capacità e consenso, Nilano 1978, s. 61.

8 „Nusquam libertas tam necessaria quam in matrimonio”. Dec. C. Pinto z 25.11.2011, RRD 103 (2011), s. 454, n. 11,

9 Dla usprawiedliwienia ważności małżeństwa zawartego pod wpływem podstępu autorzy wysuwali różne racje: pragnienie nadania małżeństwu stabilności; uznawanie, że w podstępnym wprowadzeniu w błąd brak jest elementu subiektywnego, i dlatego dolus jest dobry; przekonanie, że małżeństwo jest instytucją do udzielenia łaski uświęcającej. Zob. Dec. C. Arellano Cedillo z 18.04.2012, RRD14 (2012), s. 119 , n. 5 .
} 
małżeństwa nie byłaby ich zgoda małżeńska, lecz błąd spowodowany podstępem ${ }^{10}$.

Zasadę niezastępowalności zgody małżeńskiej (kan. 1057 \$1 KPK), znaną już w prawie rzymskim ${ }^{11}$, przypomina orzeczenie c. Pinto z 25 listopada 2011 roku. Zajmuje ona, jak stwierdził Paweł VI w przemówieniu do Roty Rzymskiej z 9 lutego 1976 roku, najwyższe miejsce w doktrynie kanonicznej i teologicznej przyjętej z tradycji i często przypominanej przez Kościół ${ }^{12}$.

„Dlatego też, głosi wyrok c. Arellano Cedillo z 1 czerwca 2011 roku, jeśli powołany kanon [1098 - W.G.] jest tak rozumiany, to naruszenie tego prawa niesie ze sobą to, że zgoda małżeńska kierowana jest ku przedmiotowi całkowicie różnemu od tego, który nupturient postanawia wybrać; powstaje wówczas sytuacja, w której wolność i autentyczność jego konsensu doznaje zniweczenia"13. Sprawca podstępu, za pomocą kłamstwa fałszuje odbiór poznawczy drugiej strony, manipulując $\mathrm{w}$ ten sposób procesem decyzyjnym drugiego nupturienta w celu zdeterminowania jego wyboru małżeńskiego.

„Całkowity dar z ciała, stwierdza Pinto w orzeczeniu z 25 listopada 2011 roku (przytaczając słowa Jana Pawła II), byłby zakłamaniem, jeśliby nie byłby znakiem i owocem pełnego oddania osobowego, w którym jest obecna cała osoba, również w swoim wymiarze doczesnym. Jeżeli człowiek zastrzega coś dla siebie lub rezerwuje sobie

10 Zob. Dec. C. Huber z 28.04.2010, RRD 102 (2010), s. 151, n. 4; Zob. W. GóraLSKI, G. DZIERżon, Nieważność małżeństwa zawartego pod wpływem podstępu..., s. $173-174$.

11 „Nuptias enim non concubitus, sed consensus facit”. Dig. 35, 1, 15.

12 Paulus VI, Allocutio ad Rotam Romanam diei 9 februarii 1976, AAS 68 (1976), s. 206.

13 „Quocirca si canon supradictus sic legitur, violatio huius iuris secumfert ut consensus nupturientis dirigatur in obiectum prorsus dissimile ab eo quod eligere censeat; exinde fit ut libertas necnon authenticitas eius consensus vitietur". DEC. C. Arellano Cedillo z 01.06.2011, RRD 103 (2011), s. 270, n. 6; Zob. także Dec. C. ERlebach z 04.10.2012, RRD 104 (2012), s. 51, n. 4. 
możliwość zmiany decyzji w przyszłości, już przez to samo nie oddaje się całkowicie"14.

Mówiąc o owym wzajemnym przekazaniu siebie przez kontrahentów, w tymże wyroku c. Pinto wymieniony ponens podkreśla, że „Zgody małżeńskiej nie można oddzielać od rzeczywistej autodonacji, która powinna być prawdziwie małżeńska, i która wymaga, by jeden i drugi kontrahent przekazał drugiej stronie adekwatny obraz siebie, który odpowiada rzeczywistości. W przeciwnym wypadku, jeśli ktoś przekazywałby jakiś rodzaj siebie samego, który w istocie różni się od prawdy, fałszowałby przedmiot zgody małżeńskiej drugiej strony, który nie odpowiadałby rzeczywistości”"15.

Zdaniem Pinto, wśród przyczyn, które mogą spowodować wadę konsensu małżeńskiego z powodu bardziej lub mniej poważniejszego braku prawdziwej autoderminacji, wymienia się podstęp ${ }^{16}$. „Choć nikt nie ma prawa do znalezienia męża lub żony bez braków, dodaje sędzia, wszyscy mają prawo, aby zgoda małżeńska udzielona przez drugą stronę wyrażała dar, i to szczery i bez podstępu, owej osoby, jaką jest realnie"17.

Wymownym przykładem dobrowolnego i istotnego braku szczerości w małżeńskim oddaniu się jest symulacja. Jeszcze poważniejszym przypadkiem jest tutaj zafałszowanie autodonacji poprzez podstęp - zarówno ze strony sprawcy podstępu, jak i wprowadzonego w błąd, ponieważ z powodu braku właściwego poznania drugiej

14 Dec. C. Pinto z 25.11.2011, RRD 103 (2011), s. 456, n. 12; Zob. Jan PaweŁ II, Adhortacja apostolska „Familiaris consortio” (22.11.1981), Częstochowa 1982, n. 11. 15, „...] coniugalem consensensum seiungi non posse a germana autodonatione, quae ut reapse coniugalis sit, requirit ut uterque contrahens adaequatam imaginem sui alteri praebeat, quae realitati correspondeat. Secus si quis aliquam speciem suiipsius donaret, quae revera substantialiter differt a veritate, vitiaretur obiectum consensus alterius partis, quod realitati non corresponderet”. DEC. C. Pinto z 25.11.2011, RRD 103 (2011), s. 456, n. 12.

16 Tamże.

17 „Quamvis nemo gaudet iure inveniendi maritum vel uxorem sine defectibus, omnes ius habent ut consensus matrimonialis ab altera parte datus repraesentet donum, sincerum quidem ac sine dolo, istius personae sicut realiter est”. Tamże. 
strony, pochodzącego z podstępu, prawdziwa i naturalna autodeterminacja doznaje przeszkody i poważnej rany w wolności wyboru, do którego ma prawo ${ }^{18}$. Racja kan. 1098, podkreśla się w wyroku c. Erlebach z 14 grudnia 2012 roku, tkwi w naturalnej słuszności, zgoda małżeńska wymaga bowiem wysokiego stopnia wzajemnej uczciwości stron, a w szczególności niesie ze sobą ochronę wolności osoby wprowadzonej w błąd w odniesieniu do zawieranego małżeństwa"19.

W wielu orzeczeniach podkreśla się, że eksponowanie wolności nupturientów w wyborze małżeńskim stanowi wyraz personalizmu, na który zwrócił uwagę Sobór Watykański $\mathrm{II}^{20}$. Już w orzeczeniu c. Burke z 25 października 1990 roku stwierdzono, że podstęp uniemożliwia wzajemne interpersonalne oddanie współmałżonków ${ }^{21}$.

Działanie podstępne godzi więc przede wszystkim w proces poznawczy nupturienta do tego stopnia, że czyni nieważną wyrażoną zgodę małżeńską. Zasadniczą więc ratio legis kan. 1098 KPK jest ochrona procesu formacyjnego zgody małżeńskiej ${ }^{22}$. Należy powiedzieć, stwierdza się w orzeczeniu c. Erlebach z 4 października 2012

\footnotetext{
18 Tamże, n. 13.
}

19 „Ratio can. 1098 radices agit in aequitate naturali - consensus matrimonialis requirit enim altam partium reciprocam honestatem - et potissime prae se fert protectionem libertatis personae deceptae in ordine ad matrimonium contrahendum”. Dec. c. Erlebach z14.12.2012, RRD 104 (2012), s. 383, n. 4. Ponens odwołał się tutaj do pracy: M. T. Romano, La rilevanza invalidante del dolo sul consenso matrimoniale (can. 1098 C.I.C.): dottrina e giurisprudenza, Roma 2000, s. 95-145.

20 Zob. Dec. C. Sciacca z 25.06.2010, RRD 102 (2010), s. 263, n. 2; Dec. C. Pinto z 25.11.2011, RRD 103 (2011), s. 455. n. 11; DEC. C. SABLE z 10.10.2012, RRD 104 (2012), s. $260-261$, n. 6.

21 Dec. C. Burke z 25.10.1990, RRD 82 (19990), s. 724, n. 6; „,Canon 1098 utique in christiano personlismo radicatus videtur. Qin attenuet obligationem assumendi personelem responsabilitatemn pro electionibus libere factis, dirigitur ad turionem libertatis personalis contra dolosam instrumentalizationem ex parte aliorum (coram Burke, sent. diei 18 lilii 1996, RRDeuyi7nc., vol. LXXXVIII, p. 541, n. 22)”. DeC. C. SCIACCA Z 25.06.2010, RRD102 (2010), s. 264, n. 4.

22 Zob. Dec. C. Erlebach z 04.10.2012, RRD 104 (2012), s. 252, n. 5; G. Dzierżon, „Ratio legis” kan. 1098 KPK oraz problem jego retroaktywności, w: W. GóRALsKi, G. Dzierżon, Nieważność małżeństwa zawartego pod wpływem podstępu..., s. 311. 
roku, że kan. 1098 został ustanowiony jako pewna ochrona dla ofiary podstępu ${ }^{23}$. W powołanym wyżej orzeczeniu c. Pinto (z 25 listopada 2011 roku) wymowny jest cytat wypowiedzi P. Huizinga, konsultora Papieskiej Komisji do Rewizji KPK (w Zespole De matrimonio), w którym wybitny kanonista stwierdza, że kiedy podstęp dokonywany jest przez stronę, ona wie, że jej wola nie jest spójna z wolą drugiej strony co do przedmiotu konsensu, ponieważ wola drugiej strony zmierza do przymiotu, który de facto nie istnieje. Taka rozbieżność przedmiotu woli wprowadzona przez działanie podstępne, jest ostateczną racją wady konsensu i nieważności małżeństwa ${ }^{24}$.

\section{Działanie podstępne}

Pierwszym elementem konstytutywnym figury prawnej określonej w kan. 1098 KPK jest podstępne wprowadzenie w błąd, inaczej działanie podstępne. „Kto zawiera małżeństwo zwiedziony podstępem dokonanym dla uzyskania zgody małżeńskiej [...]”, brzmią pierwsze słowa kanonu.

Gdy chodzi o określenie działania podstępnego, to w orzeczeniach rotalnych niejednokrotnie nawiązuje się do definicji sformułowanej przez prawnika rzymskiego Labeona (I w. przed Chr.) przekazanej przez Ulpiana. Brzmi ona następująco: „Wszelka przebiegłość, oszustwo, machinacja podjęta w celu wywołania u drugiego błędu, oszukania go, zwiedzenia"25. Prawo rzymskie nie traktowało nieważności ipso iure umowy z powodu podstępu, lecz wprowadzonemu w błąd przysługiwało działanie cywilne w celu uzyskania naprawienia szkód, które mógł ponieść wskutek podstępu, albo w celu otrzymania pełnej restytucji.

\footnotetext{
23 Dec. c. Erlebach z 04.10.2012, RRD 104 (2012), s. 252, n. 5.

24 P. Huizing [wypowiedź z 11.11.1968], „Communicationes” 33 (2001), s. 84, n. 2; Dec. C. Pinto z 25.11.2011, RRD 103 (2011), s. 458, n. 13.

25 „Labeo se dolo definitionem praesentat, quaea b Ulpiano traditur et sic sonat: «Omnis calliditas, fallacia, machinatio ad circumveniendum, fallendum, decipiendum alterum adhibita» (Dig. 4, 3, 1, 2)”. Dec. C. Huber z 28.04.2010, RRD 102 (2010), s. 150, n. 3; Dec. C. Arellano Cedillo z 01.06.2011, RRD 103 (2011), s. 269, n. 4.
} 
W rzeczywistości, jak głosi wyrok c. Arellano Cedillo, według dawnych autorów istniało stopniowanie w znaczeniu słów: calliditas, fallacia, machinationes. Wyjaśnił to starannie Hostiensis uznając, że calliditas polega na milczeniu, fallacia na oszukaniu, machinatio na sztuce słów ${ }^{26}$.

Natomiast w prawie kanonicznym G. Michiels określa podstęp jako świadome i podstępne wprowadzenie drugiego błąd w celu spełnienia określonego aktu prawnego ${ }^{27}$. Chodzi zatem o działanie, poprzez które dokonuje się świadome i kłamliwe oszukanie kogoś drugiego, by powziął określony akt prawny; jest to więc działanie skierowane w celu wywołania błędu. Można powiedzieć, że podstęp powoduje bezpośrednio błąd, a pośrednio, poprzez błąd, wpływa na wolę, kierując ją ku zawarciu małżeństwa ${ }^{28}$.

Działanie podstępne może mieć charakter pozytywny i negatywny. W pierwszym przypadku (tzw. fałszowanie; dolus commissivus) sprawca podstępu manifestuje coś, co nie jest prawdą (zaprzecza prawdzie lub głosi fałsz) w drugim zaś (tzw. dysymulacja; dolus omissivus) symuluje coś lub zataja prawdę, którą druga strona ma prawo znać $^{29}$. Gdy chodzi o podstęp negatywny, w orzeczeniu c. Sciacca z 25 czerwca 2010 roku przypomniano, że silentium dolosum ma miejsce wówczas, gdy chodzi o istotny przymiot dla wspólnoty małżeńskiej; nupturient nie może przemilczeć braku takiego przymiotu ${ }^{30}$. Nie ma natomiast charakteru podstępnego przemilczenie dotyczące różnych

\footnotetext{
$26 \mathrm{X}, 3,3,17$, w: Lectio in quinque Decretalium libros, Parisiis 1512.

27 G. Michiels, Principia generalia de personis in Ecclesia, Parisiis-Tornaci-Romae 1955, s. 660 .

28 W. Góralski, Analiza normy prawnej, w: W. Góralski, G. Dzierżon, Nieważność małżéstwa zawartego pod wpływem podstępu..., s. 90-92.

29 Dec. C. Erlebach z 04.10.2012, RRD 104 (2012), s. 252, n. 5; Dec. C. ErleBACH z 14.12.2012, RRD 104 (2012), s. 382-383, n. 3; Dec. C. Arellano Cedillo z 01.06.2011, RRD103 (2011), s. 269, n. 4.

30 Dec. C. Sciacca z 25.06.2010, RRD 102 (2010), s. 264, n. 6; Zob. M. F. Pompedda, Annotazioni sul diritto matrimoniale nel nuovo Codice Canonico, w: M. F. PompeddA (red.) Studi di diritto matrimonial canonico, Milano 1993, s. 230.
} 
aspektów osobowości, które nie mają większego znaczenia dla wspólnoty życia małżeńskiego ${ }^{31}$.

W tymże orzeczeniu c. Sciacca ponens stawia znaczące pytanie: Czy istnieje obowiązek nupturienta, nie tylko moralny, ale i prawny, ujawnienia współpartnerowi swoich przymiotów, które mogą mieć poważny wpływ na przyszłą wspólnotę małżeńską. Na pytanie to odpowiada pozytywnie, zważywszy że wspólnota małżeńska jest rzeczywistością egzystencjalną, nie mniej znaczącą niż prawna, która jednakowo dotyczy obu stron i nakłada na nie jednakowe obowiązki i zadania $^{32}$. Taki obowiązek należy jednak odnieść jedynie do tego, co jest istotne dla wzajemnego oddania się małżeńskiego, nie zaś do elementów przypadłościowych albo tylko doskonalących to oddanie ${ }^{33}$.

Gdy chodzi o kwestię dotyczącą stopnia pewności wymaganej u sprawcy podstępu co do istnienia przymiotu, który może poważnie zakłócić wspólnotę życia małżeńskiego, to zazwyczaj bierze się pod uwage jedynie pewność lub przynajmniej przekonanie o istnieniu tego rodzaju przymiotu w umyśle sprawcy podstępu. Co jednak stanie się, gdy działający podstępnie ma wątpliwość, czy ów przymiot rzeczywiście istnieje lub nie? Odpowiedzi na to pytanie poszukuje się m.in. w orzeczeniu c. Erlebach z 4 października 2012 roku. Wymieniony ponens przyjmuje, że w rozwiązaniu tego problemu należy odnieść się do ratio legis kan. $1098 \mathrm{KPK}$, a nie jest nią (jak niektórzy przyjmują) sankcja w stosunku do sprawcy podstępu, lecz ochrona wolności kontrahenta wprowadzonego w błąd. Co się więc tyczy postawionej kwestii, niewiele znaczy stopień pewności sprawcy podstępu co do

\footnotetext{
31 W. Góralski, Analiza normy prawnej ..., s. 98.

32 Dec. C. SCIACCA z 25.06.2019, RRD 102 (2010), s. 265.

33 Zob. Dec. C. Burke z 25.10.1990, RRD 82 (1990), s. 731, n. 6; „Sed cogniio suipsius alteri parti tradenda non necessario totalis esse debet. Adsunt etiam limites in hoc: merito tamen affirmatur ius ad compartem cognoscendum, vel mutuam auto-revelationis obligationem, non esse absque ullis limitibus, cum respiciat tantum ad id quod autodonationi coniugali essentiale sit, non vero elementa accidentalia, vel tantum perfectiva huius donationis (cf. coram Burke, sent. diei 25 octobris 1990, ibid., vol. LXXXII, p. 724, n. 7)”. Dec. C. Arellano Cedillo z 01.06. 2011, RRD 103 (20011), s. 273, n. 6.
} 
określonego przymiotu, który staje się przedmiotem działania podstępnego, przede wszystkim bowiem ważny jest skutek, który powoduje podstęp, a więc błąd u osoby zwiedzionej podstępem. Wynika stąd, konkluduje sędzia rotalny, że również w przypadku wątpliwości pozytywnej i prawdopodobnej występującej u sprawcy podstępu należy przyjąć, iż dokonała się deceptio dolosa stosownie do kan. 1098 KPK, co ma duże znaczenie przede wszystkim w przypadku podstępu negatywnego. Nie odnosi się to jednak, i to z różnych powodów, do przypadku zwykłej możliwości dalszej lub wątpliwości, która nie urasta do rangi wątpliwości pozytywnej i prawdopodobnej ${ }^{34}$.

Mając na uwadze aspekt dotyczący zwiedzionego podstępem, można mówić o podstępie będącym przyczyną, czyli o podstępie determinującym (dolus causam dans seu determinans) i o podstępie przypadłościowym (dolus incidens). Pierwszy ma miejsce wówczas, gdy tak determinuje wolę działającego (ofiarę podstępu), iż bez błędu spowodowanego przez podstęp drugiej osoby w żaden sposób nie podjąłby umowy; drugi zaś istnieje wtedy, gdy nie wpływa na samą determinację działającego, choć może wpłynąć na drugorzędne kwestie umowy, tak iż zostałaby ona dokonana także bez błędu spowodowanego podstępem, choć może pod innymi warunkami, mniej obciążającymi działającego ${ }^{35}$.

Aby miała miejsc deceptio dolosa, musi nastąpić jej oczekiwany skutek, co wynika z tekstu kan. 1098 KPK: „Qui matrimonium init deceptus dolo”. Może być bowiem i tak, że ktoś uchodzący za zwiedzionego podstępem, z działania podstępnego jest zadowolony, ponieważ przymiot drugiej osoby stwarza mu możliwość wspierania sprawcy podstępu, np. gdy cierpi na jakąś chorobę ${ }^{36}$. Działanie podstępne nie osiąga wówczas skutku, gdyż nie determinuje woli drugiej strony.

\footnotetext{
34 Tamże.

35 Dec. C. Arellano Cedillo z 18.04.2012, RRD 104 (2012), s. 120, n. 7. Ponens posłużył się tutaj fragmentem pracy: G. Michiels, Principia generalia de personis in Ecclesia ..., s. 661-662.

36 Zob. Dec. c. Huber z 26.04.2010, RRD 102 (2010), s. 151, n. 6.
} 
Ze zwrotu kan. 1098 KPK: „[...] zwiedziony podstępem dla uzyskania zgody małżeńskiej [...] jasno wynika, że celem działania podstępnego jest uzyskanie przez działającego zgody małżeńskiej. Ustawodawca, jak podkreśla Huber w swoim orzeczeniu z 28 kwietnia 2010 roku, expressis verbis chciał wskazać ów cel zamierzony przez sprawcę podstępu. W ten sposób dokonał powiązania przyczynowości między podstępem i zgodą małżeńską, tak iż małżeństwo powinno być zawarte na skutek podstępu, i to podstępu tzw. bezpośredniego ${ }^{37}$. Jedynie dolus directus (nie zaś dolus indirectus) ma moc unieważnienia konsensu małżeńskiego. Jeśli więc działanie podstępne jest skierowane do osiągnięcia innych celów, nie ma żadnego wpływu na zgodę małżeńską i małżeństwo należy uznać za ważne ${ }^{38}$. Gdy dolus podejmowany jest np. dla obrony honoru własnego lub rodziny, nie wywiera żadnego wpływu na zgodę małżeńską i nie czyni małżeństwa nieważnym ${ }^{39}$. Jeśli jednak ktoś ma na uwadze inne cele działania podstępnego, należy je ocenić w świetle możliwego obowiązku moralnego dotyczącego odkrycia przymiotu negatywnego dla życia małżeńskiego, i dlatego przynajmniej w przypadku milczenia o takim przymiocie, w niektórych okolicznościach, może być powzięte przez sędziego domniemanie sędziowskie (praesumptio hominis) o istnieniu, przynajmniej w sposób przyporządkowany, intencyjności, stosownie do kan. $1098 \mathrm{KPK}^{40}$.

Sprawcą podstępu może być nie tylko kontrahent, lecz również osoba trzecia, zarówno w przypadku podstępu pozytywnego, jak

37 Tamże; Ponens odwołał się tutaj do Dec. c. Civili z 08.11.2000, RRD 92 (2000), s. 604 , n. 6.

38 Dec. C. Arellano Cedillo z 18.04.2012, RRD 104 (2012), s. 121, n. 8b.

39 „Si dolus ad alios fins assequendsos dirigatur, v.gr. ad proprium vel familiae honorem tutandum, nullum influxum in consensu exercet, et matrimonium validum censendum est”. Dec. c. Arellano Cedillio z 01.06.2011, RRD 103 (2011), s. 272, n. 6. Ponens powołał się tutaj na Dec. C. BRuno z 19.11.1993, RRD 85 (1993), s. $674-675$, n. 4 a.

40 Dec. c. Erlebach z 14.12.2012, RRD 104 (2012), s. 383, n. 3; Zob. także Dec. C. ErLEBACH z 31.01.2002, RRD 94 (2002), s. 45, n. 4d; „Communicationes” 9 (1977), s. 372. 
i negatywnego ${ }^{41}$. Wypowiedziała się w tej kwestii Papieska Komisja do Rewizji KPK podczas swojej szóstej sesji ${ }^{42}$. Jednoznaczne jest tutaj również stanowisko judykatury rotalnej.

\section{Błąd jako skutek działania podstępnego}

Jak już wyżej wspomniano, integralnym elementem figury prawnej określonej w kan. 1098 KPK jest faktyczne popadnięcie w błąd przez ofiarę działania podstępnego. Jeśli druga strona (wprowadzana w błąd), mimo zastosowanego wobec niej podstępu, nie popadnie w błąd, wówczas nie zachodzi deceptio dolosa ${ }^{43}$. Między bowiem działaniem sprawcy podstępu a błędem powstającym u ofiary takiego działania powinien zachodzić związek przyczynowy. Można zatem przyjąć, że podstęp prawnie relewantny staje się takim na skutek błędu ofiary działania podstępnego. O nieważności małżeństwa nie przesądza więc sam podstęp, lecz błąd spowodowany podstępem ${ }^{44}$.

Związek przyczynowy między podstępem i błędem nie zachodzi wówczas, gdy podstęp ma charakter przypadłościowy (dolus incidens), kiedy to działanie sprawcy podstępu nie jest przyczyną „napędową” konsensu małżeńskiego ofiary podstępu, gdyż także w sytuacji braku podstępu nupturient powziąłby zgodę małżeńską ${ }^{45}$.

W wyroku c. Arellano Cedillo z 1 czerwca 2011 roku ponens podkreśla, że w sytuacji podstępu zawsze ma miejsce błąd, czyli fałszywe przedstawienie jakiejś rzeczy, w tym przypadku, jakiegoś przymiotu. Nie wystarczy ignorancja ani zwykły błąd, lecz wymaga się błędu, który powstał wskutek machinacji powziętej w celu oszukania (przynajmniej przez milczenie w celu ukrycia przymiotu) kogoś drugiego,

41 Zob. Dec. C. Stankiewicz z 27.01.1994, RRD 86 (1994), s. 67, n. 4.

42 Zob. „Communicationes” 3 (1971), s. 77.

43 Dec. C. Arellano Cedillo z 01.06.2011, RRD 103 (2011), s. 269, n. 4.

44 Dec. C. Arellano Cedillo z 18.04.2012, RRD 104 (2012), s. 119; Zob. T. Zarraga Colmenares, El dolo $n$ El Derecho matrimonial canónico y su fundamentación jurídica, Navarra 1999, s. 358.

45 Zob. Dec. C. StAnkiewiCz z 27.01.1994, RRD 86 (1994), s. 67, n. 4. 
aby wyraził zgodę małżeńską ${ }^{46}$. Przytaczając fragment orzeczenia c. Stankiewicz z 27 stycznia 1994 roku $^{47}$, wymieniony ponens stwierdza: „Przede wszystkim wymaga się, by machinacja zastosowana w celu oszukania drugiego, rzeczywiście wywołała swój skutek w osiągnięciu deceptio dolosa powodując błąd poznawczy, co determinuje oszukanego do zawarcia małżeństwa [...] Ma to miejsce wówczas, gdy deceptio dolosa staje się przyczyną zawarcia małżeństwa; w przeciwnym razie strona oszukana, gdyby nie było podstępu, nigdy nie zawarłaby małżeństwa. Nie wystarczy więc podstęp czysto incydentalny, który nie wpływa na determinację kontrahenta, gdyż on, niezależnie od podstępu, i tak zawarłby małżeństwo. Jeśli bowiem nupturient, mimo zwiedzenia podstępem chciałby rzeczywiście zawrzeć małżeństwo, nie można mówić, że na skutek zastosowanego podstępu doznał $\mathrm{w}$ istocie rzeczy poważnego i niesprawiedliwego naruszenia wolności, które spowodowało nieważność zgody małżeńskiej"48.

Tenże audytor rotalny, w innym orzeczeniu przestrzega przed myleniem błędu i podstępu. „Podczas gdy w błędzie podmiot błądzący otrzymuje błędny sąd co do przedmiotu zgody małżeńskiej i powinien być uważany za autora braku zgodności lub spójności między jego ideą i rzeczywistością, która jest różna albo ukryta, to gdy chodzi o podstęp, jego sprawcą jest druga lub trzecia osoba, która

46 „Non sufficit ignorantia neque simplex error, sed requiritur error ob machinationem ad decipiendum (saltem silentium ad celandam qualitatem) alterum ut consensum matrimonialem det”. Dec. c. Arellano Cedillo z 01.06.2011, RRD 103 (2011), s. 270, n. 5.

47 DeC. S. StANkiEwicz z 27.01.1994, RRD 86 (1994), s. 67, n. 22.

48 „Imprimis requiritur ut machinatio ad decipiendum alterum adhibita revera effectum suum sortiatur in consequenda deceptione dolosa, errorem cognitionem efficiente, quae deceptum determinet ad celebrandum matrimonium [...] Ique obvenit, si deceptio dolosa det causam matrimonio ineundo; secus pars recepta, hoc est exclusa deceptione, matrimonium nullatenus celebrasset. Non sufficit igitur dolus mere incidens, qui in determinationem contrahentis non influit, cum ipse, dolo omisso, matrimonium pariter inivisset. Si enim nupturiens non obstante deceptione matrimonium revera inire voluisset, dici nequit ipsum ex dolo incidenti reapse subiisse gravem libertatis laesionem atque iniustam, quae nullitatem consensus eficeret”. Dec. C. Arellano Cedillo z 01.06.2011, RRD 103 (2011), s. 272, n. 6e. 
poprzez swoje działanie machinacyjne wymyśla lub przedstawia fałszywą rzeczywistość tak, by wzbudziła w podmiocie zwiedzionym podstępem jawnie prawdziwe rozumienie przedmiotu, który in se i per se jest fałszywy" 49 .

W tym samym wyroku Arlleano Cedillo zwraca uwagę na różnicę zachodzącą pomiędzy błędem i warunkiem. Różnicę tę widać w pochodzeniu: warunek powstaje na skutek wątpliwości, która trwa w umyśle co do istnienia przymiotu, w zawiązku z czym ktoś „zabezpiecza się" stawiając warunek. Przeciwnie, error dans causam rodzi się z przekonania, w którym ktoś fałszywie tkwi albo jest przekonany o istnieniu przymiotu ${ }^{50}$.

Jeśli mimo działania podstępnego błąd u jego ofiary de facto nie nastąpi albo kontrahent zwiedziony podstępem pozna prawdę przed zawarciem małżeństwa, nie można przyjąć do instrukcji tytułu nieważności z kan. $1098 \mathrm{KPK}^{51}$.

Związek przyczynowy zachodzący między działaniem podstępnym a powzięciem zgody małżeńskiej przez ofiarę takiego działania akcentuje się w orzecznictwie rotalnym szczególnie w aspekcie dowodzenia ${ }^{52}$.

Jeśli działanie podstępne nie determinuje konsensu małżeńskiego współkontrahenta, gdyż zawarłby małżeństwo również wówczas, gdyby podstęp nie miał miejsca, mamy wówczas do czynienia z tzw. podstępem (i błędem) towarzyszącym (dolus concomitans) ${ }^{53}$.

\footnotetext{
49 „Quamvis quisque dolo deceptus erret, error et dolus confundendi non sunt. Dum in errore etenim subiectum erroneum iudicium circa consensus obiectum facit et ipse auctor est habendus defectus congruentiae vel consensionis eiusdem ideam inter et realitatem, quae diversa est vel celata, in dolo est altera vel tertia persona quae ope doli fabricat vel pepraesentat falsam realitatem adeo ut suscitet in subicto dolo decepto apparentr veram perceptionem obiecti, quod in se et per se habetur falsun”. Dec. C. Arellano Cedillo z 18.04.2012, RRD 104 (2012), s. 120, n. 6 .

50 Tamże.

51 Dec. c. De Lanversin z 12.03.1993, RRD 85 (1993), s. 155, n. 6.

52 Zob. Dec. C. Ragni z 19.12.1995, RRD 87 (1995), s. 721, n. 5.

53 W. Gór ALski, Analiza normy prawnej ..., s. 108.
} 
Podobnie jak w doktrynie, tak również i w orzecznictwie rotalnym nie uznaje się waloru unieważniającego intencji tzw. interpretatywnej (hipotetycznej) w zakresie kształtowania się zgody małżeńskiej. Odkrywając - po zawarciu małżeństwa - istnienie danego przymiotu negatywnego (lub brak danego przymiotu pozytywnego) u współpartnera, twierdzenie drugiej strony, że gdyby znała prawdę, nie zawarłaby małżeństwa, nie ma żadnego znaczenia ${ }^{54}$.

\section{Przymiot osoby jako przedmiot działania podstępnego}

W myśl kan. 1098 KPK przedmiotem podstępnego wprowadzenia w błąd (i błędu) jest „jakiś przymiot drugiej strony, który ze swojej natury może poważnie zakłócić wspólnotę życia małżeńskiego". Chodzi tu o przymiot nupturienta, który podejmuje działanie podstępne (albo podejmuje je - w stosunku do jego osoby - osoba trzecia).

Pierwsza część rozdziału jest poświęcona przymiotowi osoby in genere, w drugiej zaś zostały ukazane przymioty osoby występujące w przebadanych orzeczeniach.

\subsection{Przymiot osoby in genere}

Przymioty mogą być wielorakie: fizyczne, moralne, społeczne, kulturowe, duchowe - zarówno wrodzone, jak i nabyte; termin „przymiot” należy tutaj rozumieć szeroko (obejmuje m.in. stan cywilny, obywatelstwo, skazanie na karę itp. $)^{55}$.

Jak zauważa się w wyroku c. Huber z 28 kwietnia 2010 roku, trudność polega na określeniu przymiotu. Przez słowa „ze swojej natury” ustawodawca wykluczył jakiekolwiek czysto subiektywne rozumienie przymiotu. Podając (w kan. $1094 \$ 3 \mathrm{KPK}$ ) jako przykład przymiotu niepłodność, dał do zrozumienia, że chodzi tutaj o kryterium obiektywne w ocenie przymiotu. Gdy brak zdolności prokreacyjnej stanowi

54 Zob. Dec. C. Faltin z 30.10.1996, RRD88 (1996), s. 184-185, n. 6; W. GóRALski, Analiza normy prawnej ..., s. 109.

55 Tamże, s. 112. 
ważny moment dla życia małżeńskiego, istnieje obowiązek prawny ujawnienia tego przymiotu (negatywnego) drugiej stronie. Milczenie miałoby w tym przypadku charakter działania podstępnego ${ }^{56}$.

W trakcie prac kodyfikacyjnych po Soborze Watykańskim II konsultorzy Papieskiej Komisji do Rewizji KPK uznali, że zastosowanie zwrotu „suapte natura” miało podkreślić charakter przymiotu jako samego z siebie zdolnego obiektywnie poważnie zakłócić wspólnotę życia małżeńskiego; $w$ takim też duchu wypowiada się judykatura rotalna ${ }^{57}$.

Przedmiotem poważnego zakłócenia przez dany przymiot (pozytywny lub negatywny) jest wspólnota życia małżeńskiego. Ustawodawca nie wskazał jednak jej elementów konstytutywnych ani wykazu przymiotów, które mogą, z natury swojej, poważnie zakłócić tę wspólnotę. Niewątpliwie jednak chodzi o przymioty (pozytywne), które dotyczą cech właściwych instytucji małżeńskiej, a których brak przeszkadza lub może przeszkodzić rozwojowi normalnego życia małżeńskiego. Jednocześnie chodzi o przymioty negatywne, których istnienie stanowi analogiczną przeszkodę w życiu małżeńskim. Idzie zatem o wspólnotę małżeńską w odniesieniu do istoty, przymiotów oraz celów małżeństwa ${ }^{58}$.

Należy jednocześnie powiedzieć, że przymioty ogólne, które każdy nupturient spodziewa się znaleźć u przyszłego małżonka, z natury swojej nie mogą poważnie zakłócić spokojnego biegu życia małżeńskiego, gdyż przy dobrej woli i korzystaniu z odpowiednich pomocy powstające trudności niemal we wszystkich wspólnotach małżeńskich z niewielkich wad i braków, łatwo mogą zostać przezwyciężone ${ }^{59}$.

Jak podkreśla się w orzeczeniu c. Arellano Cedillo, w grę wchodzi nie tylko ciężkość obiektywna zakłócenia życia małżeńskiego, która jest niewątpliwie przeważająca, lecz także subiektywna, związana

56 Dec. C. Huber z 28.04.2010, RRD 102 (2010), s. 152, n. 6; Dec. C. Sciacca z 25.06.2010, RRD 102 (2010), s. 265, n. 9.

57 Zob. Dec. C. Burke z 25.10.1990, RRD 82 (1990), s. 258, n. 5.

58 DeC. C. JARAWAN Z 15.03.1994, RRD 86 (1994), s. 160, n. 7.

59 Dec. C. Arellano Cedillo z 18.04.2012, RRD 104 (2012), s. 12, n. 8d. 
ze znaczeniem przymiotu dla strony wprowadzonej w błąd. Przymiot bowiem, który dla jednego nupturienta nie ma żadnego znaczenia lub ma znaczenie niewielkie, dla innego, biorąc pod uwagę jego mentalność, kulturę i obyczajowość społeczności, w której trwa, może mieć duże znaczenie ${ }^{60}$. Zdaniem A. Stankiewicza, powinno przeważyć kryterium obiektywne, a więc ukierunkowane ku istocie, celom i istotnym przymiotom małżeństwa, choć nie wyklucza się, jako czegoś drugorzędnego, przymiotów w ujęciu subiektywnym ${ }^{61}$.

Przedmiotem wprowadzenia w błąd może być również pewien kompleks przymiotów, które w istotny sposób określają status fizyczny, moralny, religijny itp. nupturienta ${ }^{62}$.

60 „Ad gravitatem perturbationis coniugii statuendam, non solum gravitas obiectiva, quae indubie praevalens est, sed etiam gravitas subiectiva, i.e. momentum quod pars decepta tribuit qualitati, perpendenda est. Nam qualitati, quam alter nullius vel parvi momemnti habet, alter, attentis peculiari mente, cultura et moribus societatis in qua degit, magnum pondus afferre potest”. Tamże.

61 Dec. C. Stankiewicz z 27.01.1994, RRD 86 (1994), s. 69, n. 4.

62 Zob. K. Boccafola, Dolo ed errore indotto circa qualità della persona, „Monitor Ecclesiasticus" 124 (1999), s. 711; Kwestię kompleksu przymiotów poruszono w orzeczeniu c. Erlebach z 4 października 2012 roku. Wymieniony ponens stawia pytanie: Co jednak należy powiedzieć w przypadku przymiotu „kompleksowego”, tj. takiego, na który składa się istnienie przynajmniej dwóch „sub-przymiotów”, choćby tego samego rodzaju, byleby odnoszących się do różnych osób ? Przykładem jest choroba określana jako thalassemia minor (niedokrwistość, inaczej anemia), zwana niekiedy anemia mediterranea.

Thalassemia maior, sama z siebie stanowi przymiot, kontynuuje swój wywód audytor rotalny, który może poważnie zakłócić wspólnotę życia małżeńskiego, zważywszy, że stanowi poważną chorobę z poważnymi konsekwencjami - czy to w aspekcie troski o samą osobę chorą, czy to, być może, w aspekcie przyszłego potomstwa. Mimo znacznego postępu wiedzy medycznej, aktualnie brak dotąd skutecznej kuracji na tę chorobę. Natomiast inaczej jest w odniesieniu do thalassemia minor, ponieważ ten, kto jest dotknięty tą chorobą, nazwany jest „nosicielem zdrowym”. W tych przypadkach, ów stan chorobowy, który powstaje z genetycznego braku jednego genu, zazwyczaj nie niesie ze sobą trudności w życiu codziennym dla podmiotu dotkniętego tą dysfunkcją. Powstaje jednak problem w odniesieniu do przyszłego potomstwa, jeśli chorobą tą objęci są oboje rodzice. Zdaniem dr. Bruno Pinzello, który złożył w rozpoznawanej sprawie deklarację, stwierdza ponens, stan nosicielki thalassemia minor wymaga konieczności kontroli, by druga strona nie 
Dany przymiot powinien istnieć w momencie zawierania małżeństwa i być w jakiś sposób zobiektywizowany, tzn. powinien stanowić cechę nupturienta tzw. aktualną, która go określa i wyróżnia pod danym względem (fizycznym, moralnym, religijnym, itp.) ${ }^{63}$.

\subsection{Przymioty osoby w przebadanych orzeczeniach}

W interesujących nas orzeczeniach przedmiotem domniemanego wprowadzenia w błąd były różne przymioty osoby, które miały wywołać błąd u strony, wobec której skierowane było działanie podstępne.

Tak więc w sprawie Rottenburgen.-Stutgardien. (Dec. c. Huber z 28 kwietnia 2010 roku) chodziło o wprowadzenie w błąd powódki przez mężczyznę, który zataił swoją niepłodność w celu uzyskania zgody małżeńskiej współpartnerki. Zarówno w Trybunale pierwszej instancji, jak i w Rocie Rzymskiej (druga instancja) zapadł wyrok pozytywny.

$\mathrm{W}$ instancji rotalnej, w której postępowanie odbywało się w trybie zwyczajnym, zwrócono szczególną uwagę na wiarygodność stron i świadków oraz ignorancję powódki (co do niepłodności powoda). Udowodniono intencję pozwanego wprowadzenia w błąd powódki (zatajenie niepłodności), którą bardzo kochał i której nie chciał utracić. Miał nadzieję, że z powodu miłości do niego żona zrezygnuje z potomstwa. Wykazano również ścisły związek (przyczynowy) zachodzący

była nosicielem tej choroby. W takim przypadku istnieje prawdopodobieństwo w 25 procentach, że poczęte dziecko będzie dotknięte thalassemia maior, a więc poważną chorobą hematologiczną.

W przypadku tego rodzaju przymiotu „kompleksowego”, stwierdza Erlebach, jedynie przymiot zintegrowany - w użytym przykładzie thalasemia minor występująca u obojga małżonków - stanowi przymiot, o którym w kan. 1098 KPK. DEC. C. ERLEBACH z 04.10.2012, RRD 104 (2012), s. 252-253, n. 6; W. GóRALSKI, Deceptio dolosa (kan. 1098 KPK) w wyroku Roty Rzymskiej c. Erlebach z 04.10.2012 r., w: W. GóRALSKI, Matrimonium facit consensus. Z orzecznictwa Trybunału Roty Rzymskiej w sprawach o nieważność małżeństwa rozpoznanych $z$ tytułów dotyczących zgody małżeńskiej (1997-2016), Płock 2018, s. 177-178.

63 Zob. Dec. C. Ragni z 27.04.1993, RRD 85 (1993), s. 289, n. 7. 
między silentium dolosum mężczyzny i zgodą małżeńską kobiety. Jeśli pozwany ujawniłby swoją niepłodność, powódka nie zawarłaby z nim małżeństwa. Jakkolwiek nie udało się wskazać przyczyny niepłodności mężczyzny, to fakt zatajenia przezeń tego przymiotu (negatywnego) w celu uzyskania zgody małżeńskiej powódki, został udowodniony. Co więcej, utrzymywanie żony w błędzie przez męża wyrażało się w poleceniu, by we współżyciu z nim stosowała środki antykoncepcyjne, co trwało kilka lat. Ponens zaznaczył przy tym, że znajomość przyczyny niepłodności nie jest konieczna, wystarczy że impotenta generandi istniała przed zawarciem małżeństwa.

$\mathrm{W}$ postępowaniu przed turnusem rotalnym udowodniono, że kobieta zawarła małżeństwo z intencją posiadania dzieci z mężem, co potwierdzili świadkowie; w nowym małżeństwie, zawartym po rozwodzie z mężem, powódka wydała na świat córkę. Znaczące było również odejście powódki od pozwanego i wszczęcie przez nią postępowania rozwodowego po poznaniu przez nią prawdy (o niepłodności męża dowiedziała się od jego siostry $)^{64}$.

W sprawie Arretina-Cortonen.-Biturgen. (Dec. c. Sciacca z 25 czerwca 2010 roku), prowadzonej z dwóch tytułów: błędu co do przymiotu osoby męża zamierzonego przez kobietę oraz podstępnego wprowadzenia ją w błąd przez tegoż mężczyznę, w pierwszej instancji wydano wyrok negatywny z obu tytułów, natomiast w drugiej instancji zapadł wyrok pozytywny z obu tytułów. Z kolei turnus rotalny (jako trzecia instancja) uznał nieważność małżeństwa jedynie z tytułu podstępnego wprowadzenia w błąd.

Przedmiotem domniemanego wprowadzenia w błąd kobiety przez mężczyznę było jego uzależnienie od substancji psychoaktywnych „ciężkich” („dependentia a ponderosis substantiis stupefactivis”). Powódka miała fałszywy sąd, żywiąc przekonanie, że mężczyzna używa jedynie lekkich środków psychoaktywnych (trzciny); poczuła się więc wprowadzona przez niego podstępnie w błąd.

Turnus rotalny, mając na uwadze zeznania świadków, przyjął, iż ponad wszelką wątpliwość udowodniono, że już przed poznaniem

64 Dec. C. Huber z 28.04.2010, RRD 102 (210), s. 153-159. 
powódki mężczyzna był uzależniony od owych środków (heroiny), podobnie jak w momencie zawierania małżeństwa. Powódka sądziła, że używanie przez powoda „trochę trzciny”, o czym została powiadomiona przez swojego brata, nie może zmienić jej decyzji o poślubieniu narzeczonego, tym bardziej, że liczyła na to, że i od tego uzależnienia mężczyzna odstąpi. Jako paląca papierosy dała się przekonać narzeczonemu, że jej uzależnienie od ty toniu jest większe niż jego od „trzciny”.

Nie bez znaczenia było też oświadczenie pozwanego, iż w zasadzie zgadza się z treścią skargi powodowej. Przyznał też, że w okresie narzeczeństwa używał substancji zarówno „lekkich”, jak i „ciężkich”. Potwierdził ponadto, że we wspólnocie małżeńskiej używał narkotyków i był w stanie uzależnienia od nich. Uznał, że rozumie, iż powódka myślała i myśli, że została przez niego oszukana. Turnus wziął także pod uwagę mentalność powódki, jako wiejskiej, dobrej, choć naiwnej dziewczyny, która nie zdawała sobie sprawy, czym są narkotyki.

Znacząca dla rozstrzygnięcia sprawy była również reakcja powódki, gdy odkryła, iż została przez męża wprowadzona w błąd: odkrycie prawdy o nałogu męża wprawiło ją w szok i desperację. Jako osoba autentycznie religijna, początkowo usiłowała uratować swoje małżeństwo (korzystając z pomocy duszpasterza i psychologa). Gdy jednak zorientowała się, że sytuacji nie da się naprawić, zdecydowała się na separację ${ }^{65}$.

Przedmiotem sprawy Beryten.Maronitarum (Dec. c. Alwan z 9 lipca $2010 \mathrm{roku}$ ) rozpoznanej przez turnus rotalny w trzeciej instancji było udzielenie odpowiedzi na pytanie, czy miało miejsce podstępne wprowadzenie w błąd mężczyzny przez kobietę (oprócz dwóch innych tytułów nieważności). Powód, jak twierdził, miał być podstępnie wprowadzony w błąd przez pozwaną, która przekonała go o swoich przymiotach: uległości, dobrym prowadzeniu się, swojej wierze w Boga i o swojej miłości do bliźniego i o fakcie, że chciała ustabilizować się; poza tym mężczyzna dodał jeszcze inny przymiot,

65 Dec. C. Sciacca z 25.06.2010, RRD 102 (2010), s. 268-275. 
mianowicie cudzołóstwo, ponieważ po zawarciu małżeństwa dowiedział się, że przyczyną poprzedniego rozwodu pozwanej było właśnie jej cudzołóstwo.

W instancji rotalnej powód zeznał, że przed zawarciem małżeństwa miał jedynie decyzję ogólną, nie zaś per extensum. Pozwana natomiast twierdzi, że egzemplarz dekretu rozwodowego powód znał już przed zawarciem małżeństwa i nie okazał żadnej reakcji. Sędziowie rotalni uznali za wiarygodną wersję pozwanej, co oznaczało, że nie przyjęli twierdzenia powoda o popadnięciu w błąd, a tym bardziej spowodowany podstępem co do cudzołóstwa pozwanej.

Turnus rotalny nie uznał poza tym za udowodnioną narrację powoda, iż przed ślubem kobieta okazywała się osobą kochającą, szczerą i wierną, zapewniając go wielokrotnie, że będzie dobrą żoną, a już trzy dni po zawarciu małżeństwa (gdy przestał być deputowanym) okazało się, że tak nie jest, co sprawiło, że nie padł ofiarą podstępu.

Jak zauważa ponens, powód nazywa „przymiotem” nie to, co jest nim sensu stricto, o czym w kan. $820 \mathrm{KKKW}$, lecz to, co jest obietnicą przyszłego zachowania, które pozwana obiecała mu i nie dotrzymała słowa. Nie można więc tutaj mówić o przymiocie, lecz o obietnicy czynienia czegoś. Pozostaje jedynie przymiot cudzołóstwa, co do którego błąd powoda nie został udowodniony.

Poza tym powód znał przymioty pozwanej, ponieważ jej siostry i przyjaciółka rodziny wszystko o pozwanej powiedziały mężczyźnie przed zawarciem małżeństwa; niektórzy świadkowie wręcz odwodzili powoda od zawarcia związku z powódką.

Wyrok pozytywny zapadł jedynie z tytułu symulacji całkowitej po stronie pozwanej ${ }^{66}$.

W sprawie Mediolanen. (Dec. c. Arellano Cedillo z 01.06.2011 roku) chodziło ustalenie, czy miało miejsce podstępne wprowadzenie w błąd powoda przez pozwaną. W pierwszej instancji zapadł wyrok negatywny, w drugiej zaś przedmiotem postępowania był ten sam tytuł nieważności oraz tytuł (jako rozpoznany w pierwszej instancji) niezdolności pozwanej do podjęcia istotnych obowiązków

66 Dec. C. Alwan z 09.07.2010, RRD 102 (2010), s. 297-300. 
małżeńskich, ze szczególnym odniesieniem do zrodzenia i wychowania potomstwa, a w sposób przyporządkowany tytuł poważnego braku rozeznania oceniającego po stronie tejże kobiety. Zapadł tutaj wyrok pozytywny jedynie z tytułu podstępu. Po wniesieniu apelacji do Roty Rzymskiej, wymieniony Trybunał orzekł non constare e nullitate ob dolum.

Przymiotem osoby, co do którego pozwana miała wprowadzić w błąd powoda, miała być jej choroba psychiczna disturbo bipolare (zaburzenie afektywne dwubiegunowe), którą to dolegliwość - tak twierdził powód - zataiła przed nim (podstęp negatywny), co sprawiło, że popadł w błąd. Jak się jednak okazało, powód wiedział przed ślubem o chorobie kobiety.

W swoim drugim zeznaniu mężczyzna przyznał, że pozwana powiedziała mu przed ślubem, iż cierpi na wyczerpanie nerwowe i stosuje lek, lecz nie poinformowała go dokładnie o rodzaju choroby; nigdy też nie padło z jej ust określenie: ,zaburzenie afektywne dwubiegunowe" czy stwierdzenie, że chodzi o chorobę typu psychicznego.

Ciesząca się bardzo dobrą opinią pozwana, w zeznaniu zdecydowanie zaprzeczyła oskarżeniom powoda stwierdzając, iż w swoich wyjaśnieniach była „przejrzysta” i że przed zawarciem małżeństwa (gdy łączyła ich relacja sentymentalna) ujawniła mu swoje problemy, dotyczące m.in. przebytej depresji czy używania soli litowej. Dodała, że nie była zamknięta na ewentualne pytania narzeczonego, lecz on ich nie stawiał.

Będąc w stanie odmiennym, udała się wraz z narzeczonym do swojego spowiednika. W rozmowie mówiono o jej „epizdodzie depresyjnym" i zawieszeniu używania przez nią soli litowej w okresie ciąży (pozwany miał wolę posiadania dziecka zaraz po ślubie), co było koniecznością. Powód nie zgłaszał wówczas żadnej trudności.

Gdy chodzi o macierzyństwo, pozwana stwierdziła, że przed ślubem doktor G., któremu ujawniła zamiar zawarcia małżeństwa, nie odradzał jej zajścia w ciążę ani też nie oświadczył jej, że nie będzie zdolna być dobrą matką. Udała się również do własnej lekarki rodzinnej, która przeprowadziła próby płodności z wynikiem normalnym. Pozwana natychmiast ujawniła powodowi stan swojego 
zdrowia stwierdzając, że ustabilizował się z rezultatem pomyślnym do tego stopnia, że od 1994 roku nie miała epizodów zaburzeń nastroju (małżeństwo zawarto w roku 2000).

Turnus rotalny uznał, że powód nie tylko otrzymał wystarczającą informację co do stanu zdrowia psychicznego kobiety, lecz przez przyszłą małżonkę został zachęcony, by jej towarzyszył, gdy wynik analizy niosła do leczącego ją lekarza; przy okazji mógł otrzymać wszystkie bezpośrednie informacje od lekarza specjalisty G., lecz $\mathrm{z}$ tego zaproszenia nie skorzystał. Znaczące było i to, że pozwana bardzo żałowała, iż mężczyzna nie chciał więcej wiedzieć o jej stanie zdrowia i rzeczywistych skutkach co do życia małżeńskiego i prokreacji. To wyznanie kobiety potwierdził powód.

Wśród świadków znaleźli się m.in. dwaj duchowni, którzy stwierdzili, że przed ślubem powód znał nie tylko epizod tzw. wyczerpania nerwowego pozwanej, lecz również epizody depresyjne i leki, które używała pozwana. Proboszcz tej ostatniej zeznał, że podczas badania przedślubnego, na pytanie, czy zna stan zdrowia narzeczonej, odpowiedział, że zna. Zdaniem tego kapłana, powód mógł przewidzieć powtórzenie się symptomów słabego stanu zdrowia pozwanej.

Drugi z duchownych stwierdził zdecydowanie, że pozwana była całkowicie niezdolna, by wprowadzić w błąd powoda.

Sędziowie rotalni nie dopatrzyli się zatem podstępnego działania pozwanej, która zataiłaby jakiś istotny przymiot, który z natury swojej mógł poważnie zakłócić wspólnotę życia małżeńskiego ${ }^{67}$.

Sprawę Tridentina. (Dec. c. Pinto z 25 listopada 2011 roku), turnus rotalny rozpoznał $z$ tytułu poważnego braku rozeznana oceniającego po stronie mężczyzny (jako trybunał drugiej instancji) oraz z tytułu podstępnego wprowadzenia w błąd mężczyzny przez kobietę (jako Trybunał pierwszej instancji); obydwa tytuły uznano za udowodnione.

Wypada dodać, że w pierwszej instancji (Trybunał diecezjalny) zapadł wyrok pozytywny z tytułu błędu co do przymiotu osoby sprowadzającego się do błędu co do osoby (kan. 1083 KPK z 1917 roku),

67 Dec. C. Arellano Cedillo z 01.06.2011, RRD 103 (2011), s. 275-282, nn. 9-17. 
w drugiej (Trybunał Apelacyjny) wyrok negatywny, w trzeciej (Rota Rzymska działając jako trybunał pierwszej instancji) wyrok negatywny (z wprowadzonego tytułu poważnego braku rozeznania oceniającego po stronie mężczyzny).

Gdy chodzi o interesujący nas tytuł deceptio dolosa, to mężczyzna uznał, że został przez kobietę podstępnie wprowadzony w błąd co do jej fałszywej ciąży oraz co do jej prawdziwego stanu odnośnie do zdolności prokreacyjnej.

Mężczyzna właściwie przyjął informację narzeczonej o jej ciąży, nie zwracając uwagi na fakt jej uprzedniej choroby, choć uświadomił sobie, że na dwa lata przed zawarciem małżeństwa musiała poddać się amputacji prawej piersi (mastektomia); zawsze był blisko niej. Po dwóch latach kobieta ta zakomunikowała mu, że powinni zawrzeć małżeństwo, ponieważ spodziewa się dziecka. Powód uwierzył jej, gdyż od pewnego czasu mieli stosunki cielesne, choć z użyciem prezerwatywy. Nie czyniąc jej żadnych obiekcji ani nie prosząc o świadectwo medyczne, był po prostu szczęśliwy, że urodzi mu się dziecko; chętnie więc przystał na propozycję małżeństwa (zawartego w sierpniu 1973 roku). Uznając pozwaną za kobietę dojrzałą, uwierzył w to, co mu powiedziała. Mężczyzna oświadczył jednoznacznie, że gdyby wiedział, że narzeczona go oszukała, nie zawarłby z nią małżeństwa.

Okoliczność domniemanej ciąży kobiety jako przyczyny zawarcia małżeństwa przez powoda poświadczyli niemal wszyscy świadkowie, ukazując zależność przyczynową między machinacją pozwanej a decyzją powoda. Turnus dysponował ponadto wieloma dokumentami medycznymi dotyczącymi poważnej choroby kobiety i przebiegu jej leczenia, m.in. dokument poświadczający, że - wbrew temu, co twierdziła - przechodząc poważną terapię radiologiczną, nie mogła być w ciąży. Z akt sprawy wynika, że kobieta, nieskłoniona żadną ciążą, chciała zawrzeć małżeństwo powiadamiając podstępnie powoda o rzekomej ciąży.

Powód został pozytywnie oceniony przez wszystkich świadków, pozwana zaś niemal przez wszystkich została uznana za skłonną do kłamstwa. 
Znacząca była reakcja powoda po poznaniu pełnej prawdy. Dopiero po osiemnastu latach małżeństwa, gdy znalazł dokumenty lekarskie żony, przerwał wspólnotę życia ${ }^{68}$.

W sprawie Catanen. (Dec. c. Arellano Cedillo z 18 kwietnia 2012 roku) przedmiotem rozpoznania było domniemane wprowadzenie w błąd powódki przez pozwanego co do jego zdolności prokreacyjnej. Podczas gdy w pierwszej instancji zapadł wyrok negatywny (z wymienionego tytułu oraz z tytułu wykluczenia bonum coniugum przez pozwanego), druga instancja orzekła nieważność jedynie z tytułu podstępu. W instancji rotalnej orzeczono nieważność małżeństwa ob dolum.

W pozytywnym rozstrzygnięciu sprawy w instancji rotalnej uwzględniono bardzo dobrą opinię o wiarygodności powódki (poświadczoną m.in. przez dwóch kapłanów) oraz brak wiarygodności pozwanego, który odrzucał oskarżenie kobiety twierdząc, że dopiero dwa lata po zawarciu małżeństwa dowiedział się o swojej niezdolności prokreacyjnej (azoospermia). Bardzo ważnym dowodem okazało się zeznanie proboszcza miejsca, który wyznał, że pozwany przybył $\mathrm{z}$ żoną do biura parafialnego twierdząc, iż jego małżeństwo jest nieważne. Wyjaśniając to przekonanie wyznał duchownemu, że przed zawarciem małżeństwa był świadom swojej niepłodności, a nie chciał o tym informować narzeczonej w obawie, że odmówi zawarcia tego związku. Pozwany powiedział, że dopiero po piętnastu latach małżeństwa, w roku 2000, mając zamiar odejść definitywnie od powódki, oświadczył wobec wspomnianego proboszcza, że ją oszukał.

Powódka oraz wspomniany proboszcz stwierdzili, że przed zawarciem małżeństwa pozwany był w pełni świadomy swojej niepłodności, lecz okoliczności tej nie ujawnił. Temuż duszpasterzowi wyznał, że ukrył przed narzeczoną swoją niepłodność dla uzyskania jej zgody małżeńskiej, a wiedział dobrze, że pragnęła stworzyć prawdziwą rodzinę i być matką. Podobne pragnienie posiadania dzieci wyrażał także pozwany wobec narzeczonej.

68 Dec. C. Pinto z 25.11.2011, RRD 103 (2011), s. 463-466, nn. 18-21. 
Turnus rotalny pozytywnie odpowiedział na pytanie, czy pozwany - w momencie zawierania małżeństwa - był rzeczywiści niepłodny.

Znaczącym dowodem w sprawie okazał się również dokument wskazujący na ignorancję kobiety na temat niepłodności pozwanego, a także jej reakcja po odkryciu prawdy o niepłodności męża (odejście od niego i powrót do rodziców) ${ }^{69}$.

Sprawa Romana. (Dec. c. Boccafola z 03.05.2012 roku) dotyczyła wprowadzenia w błąd mężczyzny przez kobietę co do jej niepłodności. W pierwszej instancji wydano wyrok negatywny; w drugiej dodano dwa nowe tytuły: poważny brak rozeznania oceniającego po stronie mężczyzny i/lub niezdolność do podjęcia istotnych obowiązków małżeńskich po stronie tegoż mężczyzny (tytuły te rozpoznano tamquam in prima instantia); wyrok pozytywny zapadł jedynie $o b$ dolum. W trzeciej instancji turnus rotalny wyrok ten zreformował uznając, że podstępnego wprowadzenia w błąd nie udowodniono.

Sędziowie rotalni nie dostrzegli adekwatnej przyczyny wprowadzenia w błąd mężczyzny przez pozwaną. Poza tym przytoczono w sądzie wiele faktów sprzecznych ze sobą. Mężczyzna wyznał, że w okresie przedślubnym kobieta nie była dziewicą. Twierdził również, że symulowała ciążę, by ukryć swoją niepłodność, lecz w aktach sprawy brak dokumentów, które by o tym świadczyły. Swojego twierdzenia powód nie udokumentował, co podkreślono już w orzeczeniu pierwszej instancji: nie udowodnił ani ciąży pozwanej ani jej niepłodności, skądinąd „odwracalnej”.

Zabrakło również dowodu ze świadków, gdyż ich relacje okazały się sprzeczne. Z kolei pozwana zaprzeczyła temu, by wprowadziła w błąd powoda w celu uzyskania jego zgody małżeńskiej. Wyjaśniła, iż w okresie przedślubnym narzeczeni nigdy nie odbyli pełnego stosunku seksualnego. Nie mogła więc znaleźć się w stanie odmiennym przed zawarciem małżeństwa ani dokonać aborcji. Stwierdziła również, iż podczas życia wspólnego nigdy nie zaszła w ciążę i że - przeciwnie - niepłodnym był powód. Jak zauważa ponens, nie udało się ustalić wiarygodności stron. Wreszcie wielu świadków nie

69 Dec. C. Arellano Cedillo z 18.04.2012, RRD 104 (20120, s. 124-131, nn. 11-17. 
zna sprawy de proprio visu vel auditu. Zwrócono też uwagę na wiele niejasności w sprawie, które pozostały, mimo że rozpoznawano ją w trzech instancjach ${ }^{70}$.

Sprawa Panormitana. (Dec. c. Erlebach z 04.10.2012 roku) została rozpoznana $\mathrm{w}$ pierwszej instancji z tytułów warunku co do przyszłości postawionego przez powoda co do zdolności prokreacyjnej pozwanej oraz - subordinate - podstępnego wprowadzenia w błąd powoda przez pozwaną (z obu tytułów zapadł wyrok negatywny). Po apelacji wniesionej do Roty Rzymskiej, turnus sędziowski c. Erlebach wydał również wyrok negatywny z jednego i drugiego tytułu.

Gdy chodzi o podstępne wprowadzenie w błąd, przedmiotem działania podstępnego kobiety, jak twierdził powód, miała być jej niepłodność, czego nie udowodniono, de facto bowiem chodziło o zwykły brak poczęcia, lecz przyczyny tego, zdaniem specjalistów, nie można było przypisywać określonemu małżonkowi.

W skardze powodowej powód wspomniał również o innym przymiocie pozwanej, a mianowicie o chorobie w postaci thalassemia minor (choroba hematologiczna). W początkach ich znajomości pozwana zwierzyła się powodowi, że jest nosicielką thalassemii.

Czymś istotnym dla rozstrzygnięcia sprawy było przyjęcie tezy, w myśl której thalassemia minor jednej strony nie stanowi przymiotu, który może poważnie zakłócić wspólnotę życia małżeńskiego; taki skutek może mieć miejsce jedynie wtedy, gdy wymienionym schorzeniem są dotknięte obydwie strony.

Z zeznań powoda wynikało, że nie jest dotknięty thalassemia minor. W ten sposób powód chciał pośrednio wykazać, że został wprowadzony w błąd przez pozwaną, lecz jednoczenie stworzył dowód przeciwko sobie (w zakresie przymiotu). Jak bowiem powiedziano, występowanie tego przymiotu. tj. thalassemii jedynie u pozwanej nie wystarczy do stwierdzenia nieważności małżeństwa ob dolum zastosowanego prze pozwaną wobec powoda (poprzez przemilczenie tej dolegliwości). Zabrakło zatem istotnego elementu kan. $1098 \mathrm{KPK}$, w przypadku thalassemii można powiedzieć przymiotu

70 Dec. C. Boccafola z 03.05.2012, RRD 104 (2012), s. 135-137, nn. 8-13. 
„kompleksowego" (występującego u obu stron) ${ }^{71}$, a tym samym nie stwierdzono nieważności małżeństwa $\mathrm{z}$ tytułu deceptio dolosa ${ }^{72}$.

Sprawa Inter-Eparchialis Maronitarum (Dec. c. Sable z 10.10.2012 roku) została wniesiona z tytułów: błędu co do przymiotu żony powiązanego z podstępem, niezdolności tejże kobiety do podjęcia istotnych obowiązków małżeńskich; poza tym należało odpowiedzieć na pytanie, czy należy wydać wyrok na korzyść życia wspólnego i skłonić męża do kontynuowania życia małżeńskiego lub orzec definitywną separację z odpowiedzialności męża i skłonić go do wypłacania miesięcznej należności alimentacyjnej, i w jakiej wysokości. Trybunał wydał wyrok pozytywny jedynie z tytułu błędu męża co do przymiotu kobiety. Po apelacji pozwanej skierowanej do Roty Rzymskiej, turnus sędziowski c. Caberletti orzekł „Negative” w odniesieniu do pierwszego i drugiego tytułu oraz „Negative” co do podjęcia życia wspólnego. Odnośnie do należności alimentacyjnej Trybunał polecił zastosować kryteria określone w dekrecie pierwszej instancji. Po kolejnej apelacji pozwanej turnus rotalny c. Sable uchylił orzeczenie drugiej instancji, czyli stwierdził nieważność małżeństwa z tytułu błędu co do przymiotu kobiety zamierzonego bezpośrednio i zasadniczo, powiązanego z podstępem, stosownie do kan. $820 \mathrm{KKKW}$; gdy chodzi o pozostałe tytuły, orzeczono: „Non proponi”.

Przedmiotem błędu była zdolność prokreacyjna kobiety związana z jej wiekiem (pozwana wychodząc za mąż liczyła de facto 45 lat, a twierdziła że ma 35). Na pytanie, dlaczego pozwana bezpośrednio przed zawarciem małżeństwa zataiła swój prawdziwy wiek, sędziowie odpowiedzieli, iż uczyniła to, by nie utracić zgody małżeńskiej (powoda), którą należało wyrazić („ad consensus daturum non amittendum"). Wzięto tutaj pod uwagę związek zachodzący między wiekiem kobiety i jej zdolnością prokreacyjną. Intencja więc pozwanej (uzyskanie zgody małżeńskiej), która oszukała powoda oraz proboszcza (przy badaniu przedślubnym), okazała się jasna. Przyjęto jednocześnie, że zdolność prokreacyjna jest przymiotem, który może poważnie

71 Zob. przypis 62.

72 Dec. C. ERlebach z 04.10.2012, RRD 104 (2012), s. 253-257, nn. 8-14. 
zakłócić wspólnotę życia małżeńskiego. Nie ulegało też wątpliwości, że strony miały między sobą relacje intymne otwarte na zrodzenie potomstwa, lecz nieskuteczne. Niezdolność prokreacyjna kobiety od początku wspólnego życia powodowała jej poważne zakłócenie. Powód, który poznał prawdziwy wiek pozwanej kilka dni po zawarciu małżeństwa (przy podpisywaniu aktu ślubu), okazywał smutek i rozczarowanie, co wskazuje na jego reakcję po odkryciu prawdy.

W orzeczeniu zaznaczono, iż w rozpoznanej sprawie chodzi o błąd powiązany z podstępem. $Z$ moralną pewnością sędziowie uznali, że pozwana podstępnie zataiła przed zawarciem małżeństwa własny przymiot (wiek, a tym samym brak zdolności prokreacyjnej), tak iż po odkryciu podstępu wspólnota życia od razu doznała poważnego zakłócenia, mimo jej trwania ponad osiem i pół roku ${ }^{73}$.

W sprawie Romana. (Dec. c. Erlebach z 14 grudnia 2012 roku) chodziło o tytuł podstępnego wprowadzenia w błąd kobiety przez mężczyznę. W pierwszej instancji wydano wyrok negatywny, w drugiej zaś pozytywny. Po apelacji obrońcy węzła małżeńskiego sprawa została rozpoznana w Rocie Rzymskiej przez turnus c. Erlebach, gdzie stwierdzono nieważność małżeństwa.

Przymiotem osoby, który miał zataić pozwany, była jego choroba w postaci neurofibromatozy 1 , inaczej nerwiakowłókniakowatości (neurofibromatosis), która to dolegliwość niewątpliwie może poważnie zakłócić wspólnotę życia małżeńskiego. Ta rzadka choroba genetyczna skórno-nerwowa, dotykająca przede wszystkim skóry oraz centralnego i obwodowego systemu nerwowego, a niekiedy oczu i gośćca, rozwija się stopniowo rodząc także skutki w odniesieniu do dzieci. Jak stwierdził ekspert, właśnie w przypadku pozwanego przebyta przezeń operacja (w wieku dziewiętnastu lat) świadczy o schorzeniu relatywnie poważnym, z którym wiążą się także dotkliwe konsekwencje w stosunku do potomstwa.

Główna kwestia w sprawie dotyczyła samego podstępnego wprowadzenia w błąd kobiety przez mężczyznę co do faktu jego choroby. Gdy po raz pierwszy pozwana zauważyła u powoda (na plaży), na

73 DeC. C. SABLE z 10.10.2012, RRD 104 (2012), s. 264-267, nn. 12-19. 
rok przed zawarciem małżeństwa, plamy i bliznę na ciele pozwanego, pytała go o źródło tych rzucających się w oczy „znaków”. Pozwany uspokoił powódkę wyjaśniając, że był to efekt przebytej operacji usunięcia torbieli z nacięciem prawego żebra, a wynik histopatologiczny był negatywny. Wyjaśnienie to uspokoiło kobietę, ponieważ w wieku dwunastu lat ona także miała torbiele, które zostały wchłonięte bez dalszych problemów.

Wersja pozwanego była inna: twierdził, iż narzeczona widząc jego plamy i bliznę nie okazała zdziwienia i w ogóle nie pytała o ich pochodzenie. To on, tego samego dnia, wieczorem, wspomniał jej o swojej patologii i badaniu lekarskim, w wyniku którego stwierdzono neurofibromatozę niskiego stopnia.

Gdy każda ze stron broniła swojej tezy przytaczając stosowne dowody, należało przyjąć jedną z nich. Turnus rotalny opowiedział się zdecydowanie po stronie powódki, gdyż jej relację uznał za bardzo prostolinijną i potwierdzoną przez świadków, którzy stwierdzili, iż wiadomość o wspomnianej chorobie pozwanego otrzymała dopiero pod koniec życia wspólnego. Natomiast pozwany w wielu kwestiach okazał się sprzeczny ze sobą, zaprzeczając tezie powódki.

Znaczącym dowodem na rzecz tezy powódki okazała się okoliczność, iż jeszcze w maju 2001 roku (małżeństwo zostało zawarte 19 września 2000 roku) kobieta ta nie wiedziała o chorobie męża, który podczas wspomnianego wspólnego przebywania na plaży (w sierpniu 1999 roku) wprowadził ją w błąd co do stanu swojego zdrowia. Gdy w czerwcu 2001 roku powódka dowidziała się o chorobie męża, natychmiast przerwała życie wspólne ${ }^{74}$.

\section{Dowodzenie deceptio dolosa}

Przedmiot dowodzenia podstępnego wprowadzenia w błąd obejmuje wszystkie elementy konstytutywne tej figury prawnej. Judykatura rotalna wypracowała określone kryteria w tym zakresie, które kształtują pewność moralną sędziego, stosownie do kan. 1608.

74 Dec. C. ERlebach z 14.12.2012, RRD 104 (2012), s. 384-390, nn. 6-13. 
W sprawach, o których mowa, należy brać pod uwagę przede wszystkim zwyczajne środki dowodowe, które stanowią doniosły element w każdym postępowaniu sądowym, a są nimi: oświadczenie stron, przyznanie sądowe, dokumenty, zeznania świadków, opinie biegłych, gdy natura sprawy tego wymaga, a także wizja lokalna i oględziny sądowe; nie należy poza tym lekceważyć okoliczności.

Poszczególne elementy konstytutywne deceptio dolosa mają swoje stosowne środki dowodowe odpowiadające naturze i charakterowi tychże elementów, w szczególności przymiotowi, który w danej sprawie stanowi domniemany przedmiot podstępnego wprowadzenia w błąd.

Tak w doktrynie, jak i w orzecznictwie rotalnym uznaje się dwa rodzaje dowodów w odniesieniu do deceptio dolosa: dowód bezpośredni (probatio directa) i dowód pośredni (probatio indirecta). Dowód bezpośredni pochodzi z zeznania (sądowego i pozasądowego) sprawcy i ofiary podstępu, potwierdzonego przez wiarygodnych świadków i dokumenty. Natomiast na dowód pośredni składa się sposób działania i zachowania się ofiary podstępu wkrótce po odkryciu prawdy dotyczącej braku (lub istnienia) przymiotu, który z natury swojej może poważnie zakłócić wspólnotę życia małżeńskiego ${ }^{75}$.

W dowodzie bezpośrednim należy zwrócić uwagę na wszystkie elementy składające się na figurę prawną deceptio dolosa. Chodzi tu o ustalenie, czy w danym przypadku miało rzeczywiście miejsce działanie podstępne $\mathrm{z}$ intencją uzyskania zgody małżeńskiej drugiej strony, czy druga strona popadła wskutek tego działania w błąd i czy przymiot (pozytywny lub negatywny) będący przedmiotem podstępnego wprowadzenia w błąd mógł z natury swojej poważnie zakłócić wspólnotę życia małżeńskiego. Przymiotu nie należy mylić z osobistym motywem lub przyczyną zawarcia małżeństwa ${ }^{76}$.

„Dowód bezpośredni, czytamy w orzeczeniu c. Huber z 28 kwietnia 2010 roku, zaczyna się od przesłuchania ofiary podstępu, która

75 W. Góralski, Dowodzenie ,deceptio dolosa”, w: W. Góralski, G. Dzierżon, Nieważność małżeństwa zawartego pod wpływem podstępu ..., s. 245-250.

76 Zob. Dec. C. Burke z 25.10.1990, RRD 82 (1990), s. 722-723, n. 6. 
ma wyjaśnić sędziemu, dlaczego się uważa za zwiedzioną podstępem. Należy przesłuchać także sprawcę działania podstępnego, który powinien powiedzieć, czy działanie to podjął w celu uzyskania zgody małżeńskiej czy w innych celach. Z kolei zeznający świadkowie winni wyznać to, co wiedzą o działaniu podstępnym i jego ofierze"77. „Dowodzenie bezpośrednie, głosi wyrok c. Arelleano Cedillo z 1 czerwca 2011 roku, dotyczy zeznania sądowego, a przede wszystkim pozasądowego, zarówno zwiedzionego podstępem, jak i sprawcy takiego działania, a także zeznania wiarygodnych świadków lub potwierdzenia przez dokumenty"78.

W odniesieniu do przymiotu należy mieć na uwadze sposób dokonywania machinacji oraz charakter przymiotu będącego przedmiotem podstępu; zazwyczaj przymioty moralne wskazują świadkowie, natomiast przymioty o charakterze fizycznym wymagają badania przez biegłego ${ }^{79}$. Gdy chodzi o przymiot niepłodności, to jeśli strona wprowadzona w błąd nie pragnie potomstwa, działanie podstępne nie przynosi pełnego efektu, stąd nie można uznać nieważności małżeństwa ${ }^{80}$.

Zdaniem Hubera, dowodzenie jest szczególnie trudne w przypadku przemilczenia jakiegoś przymiotu, nie każde bowiem przemilczenie stanowi wystarczająca podstawę do stwierdzenia nieważności małżeństwa. Tylko wówczas nupturient ma obowiązek ujawnienia drugiej stronie swojego przymiotu, gdy jest on istotny dla stworzenia wspólnoty małżeńskiej ${ }^{81}$, o czym już zresztą wyżej nadmieniono ${ }^{82}$.

\footnotetext{
77 „Doli probatio incipit a confessione decepti, qui iudici explicet, cur se deceptum consideret. Audiatur deceptor, qui dicat, utum actionem dolosam dhibuerit ad consensun obtinendum, an ad alios fines consequendos. Interrogentur tetes, num quid de machinatione ex dolum patiente vel ex dolum patrante didicerint”. DEc. C. Huber z 28.04.2010, RRD 102 (2019), s. 152, n. 6.

78 Dec. C. Arellano Cedillo z 01.06. 2011, RRD 103 (2011), s. 274, n. 8.

79 Dec. C. Huber z 28.04.2010, RRD 102 (2019), s. 152, n. 6. Ponens odwołał się do Dec. C. ERlebach z 31.01.2002, RRD 94 (2002), s. 51, n. 9.

80 Dec. C. Huber z 28.04.2010, RRD 102 (2019), s. 152, n. 7.

81 Tamże.

82 Zob. Dec. C. StAnkiewicz z 27.01.1994, RRD 86 (1994), s. 68, n. 23.
} 
W wyroku c. Arellano Cedillo z 18 kwietnia 2012 roku ponens zwraca uwagę, iż w dowodzeniu należy zbadać, czy brak określonego przymiotu przed zawarciem małżeństwa nie był stronie znany, w przeciwnym wypadku niemożliwe byłoby przyjęcie podstępu ${ }^{83}$.

Gdy chodzi o dowód pośredni, opiera się on na kryterium oceny przymiotu przez domniemaną ofiarę podstępu (criterium aestimationis) oraz na kryterium reakcji tejże domniemanej ofiary podstępu po odkryciu prawdy, a więc podstępnego działania jego sprawcy (criterium reactionis).

Kryterium oceny pozwala przyjąć, że przymiot, co do którego małżonek został wprowadzony w błąd, był dlań czymś istotnym czy też nie. Nieważność małżeństwa można uznać tylko w tym pierwszym przypadku.

Gdy chodzi o kryterium reakcji, w orzeczeniu c. Arellano Cedillo z 1 czerwca 2011 roku zwrócono uwagę na zachowanie się strony wprowadzonej w błąd po skonstatowaniu, że padła ofiarą machinacji. „Jeśli po odkryciu prawdy natychmiast przerwie wspólne życie, pozostawiając duga stronę i oskarżając ją o podstęp, istnieje domniemanie o wprowadzeniu w błąd spontaniczny lub podstępny" ${ }^{44}$. Przeciwnie, gdy zwiedziony podstępem kontynuuje bez trudności i niechęci życie wspólne, a nawet wydaje na świat $\mathrm{z}$ drugą stroną dziecko, należy domniemywać, że nie został wprowadzony w błąd dla uzyskania zgody małżeńskiej ${ }^{85}$.

Jeśli ktoś, czytamy w wyroku c. Sable z 10 października 2012 roku, dla osiągnięcia urzędu w innych, mniej ważnych okolicznościach,

83 Dec. C. Arellano Cedillo z 18.04.2012, RRD 104 (2012), s. 123. n. 10.

${ }^{84}$ „Si enim ipse, detecta vritate, statim convictum coniugalem interruperit, compartem dimittendo et accusando eam deceptionis, praesumptio stat pro inductione in errorem spontaneum vel dolosum”. Dec. C. Arellano Cedillo z 01.06.2011, RRD 103 (2011), s. 274, n. 8. Ponens przytoczył tutaj fragment DeC. C. STANKIEWICZ z 27.01.1994, RRD 86 (1994), s. 70, n. 26; Dec. C. Arellano Cedillo z 18.04.2012, RRD 104 (2012), s. 122, n. 8.

85 Dec. C. Arellano Cedillo z 01.06.2011, RRD 103 (2011), s. 274, n. 8; Zob. K.E. Boccafola, Deceit and inducend error abort a personal quality, „Monitor Ecclesiasticus” 124 (1999), s. 707. 
jak dla uzyskania pracy nie tylko milczy o jakimś swoim przymiocie, jak wiek, stan małżeński, także cywilny albo zrodzenie dziecka poza małżeństwem, i w ten sam sposób czyni to w odniesieniu do dokumentów kościelnych służących zwarciu małżeństwa, nie chcąc dokonać korekty, powstaje silne domniemanie o intencji wprowadzenia w błąd dla osiągnięcia skutku ${ }^{86}$.

W dowodzie pośrednim dużą rolę odgrywają okoliczności pochodzące zarówno z okresu przed zawarciem małżeństwa, jak i z okresu po zawarciu związku ${ }^{87}$.

\section{Uwagi końcowe}

Zaprezentowane orzecznictwo Trybunału Roty Rzymskiej z lat 2010-2012 w przedmiocie podstępnego wprowadzenia w błąd pozwala stwierdzić, że wymieniony tytuł nieważności małżeństwa, wprowadzony do ustawodawstwa kościelnego przez KPK z 1983 roku, został wystarczająco przeanalizowany jako postać error facti we wszystkich jego aspektach i wymiarach. Niewątpliwie przyczynił się do tego m.in. systematyczny rozwój doktryny w tym zakresie.

Stanowiąc zrozumiały wyjątek od zasady generalnej wpisanej do kan. $125 \$ 2 \mathrm{KPK}$, figura prawna deceptio dolosa ma na celu ochronę wolności nupturienta w dokonaniu wyboru małżeńskiego. Pochodzący bowiem z podstępu brak wystarczającego poznania przymiotów współkontrahenta istotnych dla normalnego funkcjonowania wspólnoty życia małżeńskiego sprawia, że prawdziwa autodeterminacja doznaje dotkliwej przeszkody. Nie ulega wątpliwości, że troska ustawodawcy o ową swobodę wyboru współmałżonka stanowi ratio legis normy prawnej, pozostając przy tym wyrazem personalizmu.

Z samego sformułowania kan. 1098 KPK jasno wynika, że elementami konstytutywnymi tego tytułu nieważności małżeństwa

\footnotetext{
86 Dec. C. SAble z 10.10.2012, RRD 104 (2012), s. 263-264, n. 11.

87 Dec. C. Erlebach z 04.10. 2012, RRD 104 (2012), s. 253, n. 7; Dec. C. Arellano Cedillo z 18.04.2012, RRD 104 (2012), s. 123, n. 10.
} 
są: działanie podstępne z określoną intencją (uzyskanie zgody małżeńskiej drugiej strony), błąd jako skutek owego działania oraz przymiot drugiej strony, który z natury swojej może poważnie zakłócić wspólnotę życia małżeńskiego. Każdy z tych elementów został już w orzecznictwie rotalnym wystarczająco „opisany”, a linie orzecznicze raz po raz utrwalają się.

Gdy chodzi o przymiot osoby, to poza omówieniem zasad i reguł ogólnych obowiązujących w tej kwestii i stosowanych przez judykaturę rotalną, ukazane zostały qualitates personae, które były przedmiotem podstępnego wprowadzenia w błąd w sprawach, w których zapadły przebadane wyroki. Tak więc chodziło o przymioty: niepłodność mężczyzny (dwukrotnie), niepłodność kobiety (trzykrotnie), uzależnienie mężczyzny od substancji psychoaktywnych (tzw. ciężkich), choroba psychiczna kobiety (zaburzenie afektywne dwubiegunowe), fałszywa ciąża kobiety, choroba mężczyzny (neurofibromatoza); w jednym przypadku uznano, że chodziło nie tyle o przymiot osoby, ile raczej o obietnicę przyszłego zdarzenia.

Co się tyczy dowodzenia w sprawach rozpoznawanych $\mathrm{z}$ tytułu deceptio dolosa, przedmiotem są tutaj wszystkie elementy tejże figury prawnej. Praktyka orzecznicza wypracowała i w tym zakresie określone kryteria kształtujące pewność moralną sędziego. Każdy z trzech elementów konstytutywnych kan. 1098 KPK ma swoje środki dowodowe odpowiadające ich charakterowi. Szczególną uwagę poświęca się tutaj przymiotowi osoby.

Dowód bezpośredni pochodzi z zeznania (sądowego i pozasądowego) sprawcy i ofiary podstępu, potwierdzonego przez wiarygodnych świadków oraz dokumenty. Natomiast na dowód pośredni składają się criterium aestimationis (przymiot winien być obiektywnie znaczący dla wspólnoty małżeńskiej, jednak również z uwzględnieniem aspektu subiektywnego), a przede wszystkim criterium reactionis (reakcja ofiary podstępu wkrótce po odkryciu prawdy). Niemałe znaczenie mają również okoliczności pochodzące z okresu zarówno przed zawarciem małżeństwa, jak i po zawarciu go.

Wolno wyrazić przekonanie, iż orzecznictwo Roty Rzymskiej, stanowiące - w myśl kan. 19 KPK - uzupełniające źródło prawa, 
powinno znajdować właściwy punkt odniesienia w rozpoznawaniu i rozstrzyganiu spraw nullitatis matrimonii przez trybunały kościelne niższych stopni, nie tylko zresztą w obszarze deceptio dolosa.

\section{Deceptive misleading (can. 1098 CIC) in published sentences of the Roman Rota from 2010-2012 Summary}

The subject of this study is the jurisprudence of the Roman Rota Court regarding deceptive misleading (canon 1098 CIC) from 2010-2012, contained in Decisione seu sententiae. During this period, the title of nullity of marriage was included in twelve judgments; ten of them have been published.

The analysis of rotating sentences was presented in the following thematic areas: deceptive misleading as a factor protecting marriage consent; deceptive action; error as a result of deception; the attribute of a person as an object of deceptive action (in genere and in individual judgments); deceptio dolosa prove.

Undoubtedly, the jurisprudence of the Roman Rota also provides for the area of deceptive misleading, the appropriate point of reference in the resolution of nullitatis matrimonii cases by church tribunals of lower degrees of jurisdiction.

Słowa kluczowe: podstępne wprowadzenie w błąd, podstęp, błąd, przymiot osoby, wyrok.

Keywords: deceptive misleading, deceit, error, attribute of person, judgment.

\section{Nota o autorze}

Ks. Wojciech Góralski - profesor zwyczajny prawa kanonicznego, założyciel i redaktor naczelny kwartalnika „Ius Matrimoniale”, wiceprzewodniczący Stowarzyszenia Kanonistów Polskich, konsultor Roty Rzymskiej, sędzia w Sądzie Biskupim w Płocku. 